\title{
The performance of mengkuang leaf fiber reinforced low density polyethylene
} composites

\author{
N. A. Halim ${ }^{1}$, J. P. Siregar ${ }^{1}$, D. Mathivanan ${ }^{1}$, D. Bachtiar ${ }^{1}$, Z. Ghazali ${ }^{2}$, M.R.M. \\ Rejab $^{1}$, C. Tezara $^{3}$ \\ ${ }^{1}$ Structural Materials and Degradation Focus Group, Faculty of Mechanical \\ Engineering, Universiti Malaysia Pahang 26600 Pekan, Pahang, Malaysia \\ *Email: januar@ump.edu.my \\ Phone: +6094246282; Fax: +6094246222 \\ ${ }^{2}$ Human Engineering Group, Faculty of Mechanical Engineering, Universiti Malaysia \\ Pahang 26600 Pekan, Pahang, Malaysia \\ ${ }^{3}$ Department of Mechanical Engineering, Faculty of Engineering \& Quantity Surveying, \\ INTI International University 71800 Nilai, Negeri Sembilan, Malaysia
}

\begin{abstract}
The performance of mengkuang leaf fiber (MLF) reinforced low density polyethylene (LDPE) composites with different fiber volume and different mesh sizes were studied. The fibre weight percentage used in the research were $10 \%, 20 \%$, and $30 \%$ and for different fiber size were $<0.5 \mathrm{~mm}, 0.5-1 \mathrm{~mm}$, and $1-2 \mathrm{~mm}$. The extrusion and hot compression molding were used to fabricate the specimen testing. The mechanical testing performed were impact and flexural test which follows the ASTM standards D790-10 and Izod D256. It was observed that by increasing the fiber volume and fiber size, the flexural strength and the flexural modulus were increased. However the impact strength shows different results for fiber length and fibre content where the impact strength increases with fibre length but decreases with the increase of fiber content. It can be concluded that the $30 \%$ fibre content is the optimum fibre loading for the MLFLDPE composite with the flexural strength of $12.31 \mathrm{MPa}$, flexural modulus of 378.88 $\mathrm{MPa}$ and impact strength of $589.86 \mathrm{~J} / \mathrm{m}$ whereby the $1.0-2.0 \mathrm{~mm}$ fibre length is the best fibre size for the MLF-LDPE composite with the flexural strength of $12.86 \mathrm{MPa}$, flexural modulus of $267.76 \mathrm{MPa}$ and impact strength of $1511.57 \mathrm{~J} / \mathrm{m}$. In future studies fibres should undergo surface modification to increase the available surface area for reaction to increase the strength of the composite by better mechanical interlocking.
\end{abstract}

Keywords: Natural fiber; mengkuang leaf; composites; polyethylene; alkaline.

\section{INTRODUCTION}

In recent years, natural fibers has shown its importance in many mass industries such as automotive, medical, sports and construction [1]. Natural fiber composites were wellknown for their advantages [2] in most of the automotive [3] and construction [4] application based on economically and ecologically perspective [5, 6]. Natural fibers are preferred due to its advantages such as low cost, low density, low abrasion towards tools and its degradability compared to petroleum based product [7-9]. The studies regarding natural fiber reinforced composite focused on the interface between matrix and filler, morphologies, mechanical properties and thermal properties [10-16]. The concern for environmental issues such as ingestion of plastic by animals has sparked the necessity to 
study about natural fibres to replace synthetic fibres [17]. The depletion of crude oil and high cost of producing it has urged the studies for a suitable replacement for synthetic fiber [18]. The optimum mechanical properties of composites are characterized by the interface between the matrix and filler and crystallization behaviour of the matrix [19]. A lot of different natural fibers such as jute, PALF, kenaf and coir are being studied around the world as reinforcement for thermoplastic and thermoset matrices [20]. In this study will utilize MLF as a reinforcement and low-density polyethylene (LDPE) as a matrix. Mengkuang fiber is made from mengkuang leaves grown abundantly in Malaysia [21]. The study on MLF-LDPE composite is still rare which provides novelty to this study.

The most important processes involved in this study were extrusion process and compression moulding process. For the extrusion process involving the polyethylene, most commonly used screw speeds are $60 \mathrm{rpm}$ [22, 23]. In twin screw extruder machine, there are temperature of zone 2 , zone 3 , zone 4 , zone 5 , zone 6 , and die, need to be set up to enable the extrusion process. From the studies done by previous researchers, the temperatures used was in range of $145^{\circ} \mathrm{C}$ to $170{ }^{\circ} \mathrm{C}$ for all zone [11]. The processing temperature is one of the important factor in manufacturing natural fiber composite where the common processing temperature used for biodegradable polymer were not more than $200{ }^{\circ} \mathrm{C}$, this is to avoid the thermal degradation of biodegradable polymer [24]. Based on the previous research, the composite was compressed using hot and cold heated electric compressed machine at $180{ }^{\circ} \mathrm{C}$ for 5 minutes [25], followed by room temperature cooling. The weaknesses of the natural fiber composite are the poor compatibility between the fiber and the matrix of the composites. In this paper, the mengkuang leaf fiber or Pandanus tectorius with different fiber volume and different mesh sizes were used to enhance the flexural and impact strength of the LDPE.

\section{METHODS AND MATERIALS}

\section{Materials}

The material used in this experiment was mengkuang leaf or the scientific name Pandanus tectorius, and the polyethylene used in this experiment is low density polyethylene (LDPE). The LDPE name was TITANLENE LD1300YY for injection moulding. LD1300YY is a low density polyethylene resin. The melt index for LD1300YY was $20 \mathrm{~g} / 10 \mathrm{~min}$. while the density was $0.920 \mathrm{~g} / \mathrm{cm}^{3}$. The various size of mengkuang leaves used in this experiment were $>0.5 \mathrm{~mm}, 0.5-1 \mathrm{~mm}$, and $1-2 \mathrm{~mm}$ in mesh size.

\section{Preparation of Composites}

The MLF were chopped into $2-5 \mathrm{~cm}$ and then were grinded using grinder before it was sieved to the measurement of $<0.5 \mathrm{~mm}, 0.5-1 \mathrm{~mm}$, and $1-2 \mathrm{~mm}$. The fibers were then dried at $70{ }^{\circ} \mathrm{C}-80{ }^{\circ} \mathrm{C}$ using vacuum oven [26]. The composition of different fiber volumes with polyethylene are shown in Table 1 and Table 2. 


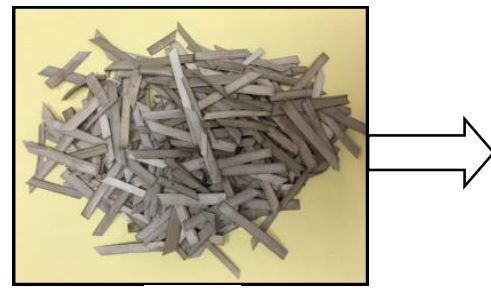

(a)

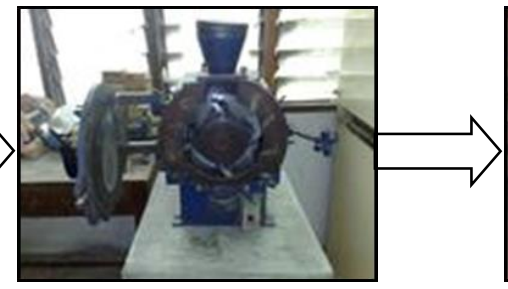

(b)

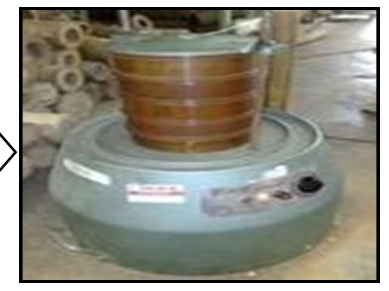

(c)

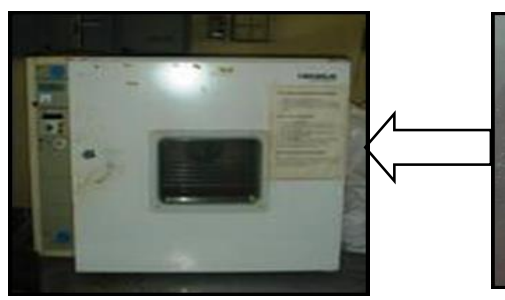

(f)

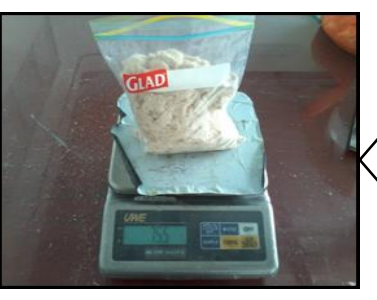

(e)

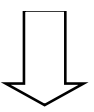

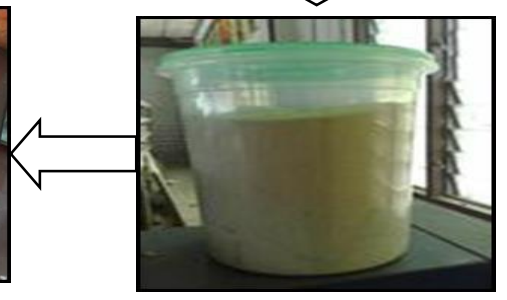

(d)

Figure 1. The preparation of MLF; (a) chopped MLF, (b) grinder, (c) sieve shaker, (d) mengkuang fiber, (e) weighing balance and (f) vacuum process.

Table 1. The composition of composite with different fiber loading.

\begin{tabular}{ccc}
\hline $\begin{array}{c}\text { Length } \\
(\mathrm{mm})\end{array}$ & Polyethylene (\%) & Fiber (\%) \\
\hline & 100 & 0 \\
$<0.5$ & 90 & 10 \\
$<0.5$ & 80 & 20 \\
$<0.5$ & 70 & 30 \\
\hline
\end{tabular}

Table 2. The composition of composite with different fiber length.

\begin{tabular}{ccc}
\hline $\begin{array}{c}\text { Length } \\
(\mathrm{mm})\end{array}$ & $\begin{array}{c}\text { Polyethylene } \\
(\%)\end{array}$ & Fiber $(\%)$ \\
\hline$<0.5$ & 90 & 10 \\
$0.5-1$ & 90 & 10 \\
$1-2$ & 90 & 10 \\
\hline
\end{tabular}

\section{Fabrication of Composites}

The extrusion process was generated by using the Prism Eurolab 16 Twin Screw Extruder. The extruder zone temperatures were set up to $168^{\circ} \mathrm{C}, 168^{\circ} \mathrm{C}, 165^{\circ} \mathrm{C}, 165^{\circ} \mathrm{C}$, and $162{ }^{\circ} \mathrm{C}, 163^{\circ} \mathrm{C}$ according to zone $1,2,3,4,5$, and 6 . The screw speed was set up to $60 \mathrm{rpm}$. The temperature and the screw speed were varied until the composite product was in proper shape and not thermally damaged (Figure 2a). Hot compression process was done by using Lotus Scientific LS-22025 25 Ton Hot \& Cold Moulding Press. The 
mould used was $20 \times 20 \times 0.3 \mathrm{~cm}$. The pressure was varied from $8 \mathrm{MPa}$ to $10 \mathrm{MPa}$. The temperature of hot compression moulding process was $165^{\circ} \mathrm{C}$ (Figure $2 \mathrm{~b}$ ).

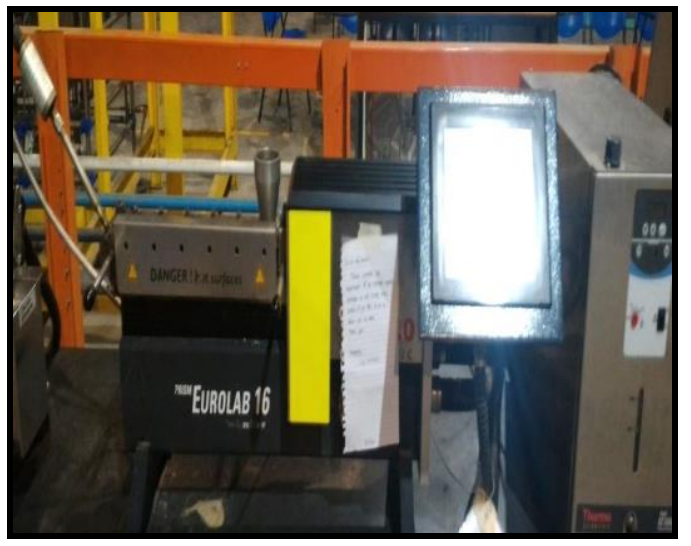

(a)

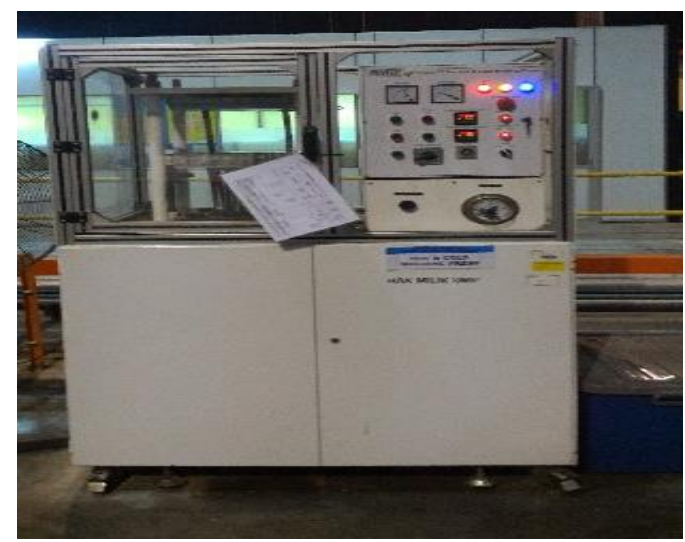

(b)

Figure 2. Fabrication of MLF- LDPE composite plates;

(a) extrusion, (b) compression moulding.

The composite was pre-pressed for 5 minutes to eliminate the bubbles and then hot pressed for 5 minutes, followed by cold press for 5 minutes. Table 3 shows the hotpressing process and condition. The obtained materials were then kept at $25^{\circ} \mathrm{C}$ with $25 \%$ humidity for 48 hours before mechanical testing. The obtained sample was cut into 7 replicates for each flexural and impact test.

Table 3. Hot pressing process and condition.

\begin{tabular}{cccc}
\hline Conditions & Pre-pressing & $\begin{array}{c}\text { Hot- } \\
\text { Pressing }\end{array}$ & Cold-pressing \\
\hline Press pressure $(\mathrm{MPa})$ & $8-10$ & $8-10$ & $8-10$ \\
Process temperature $\left({ }^{\circ} \mathrm{C}\right)$ & 165 & 165 & Room temperature \\
Pressure duration $(\mathrm{min})$ & 5 & 5 & 5 \\
\hline
\end{tabular}

\section{Mechanical Testing}

\section{Flexural Strength Test}

The samples prepared for flexural test was $12.7 \mathrm{~cm}$ x $1.27 \mathrm{~cm}$ x $0.3 \mathrm{~cm}$ in dimension and performed accordingly following ASTM D790-10. The tests were conducted using Instron Universal Testing Machine with crosshead speed of $2 \mathrm{~mm} / \mathrm{min}$. The most 5 precise result were taken into calculation of average flexural strength. 


\section{Impact Strength Test}

The impact tests were performed according to ASTM D256 Izod test standard with the dimension of $6.4 \mathrm{~cm} \times 1.27 \mathrm{~cm} \times 0.3 \mathrm{~cm}$. This test were done using Pendulum Impact Testing machine at room temperature. The most 5 precise result were taken into calculation of average impact strength.

\section{RESULTS AND DISCUSSION}

\section{Effect of fiber content on MLF-LDPE composites}

Figure 3 to Figure 5 shows the flexural strength, flexural modulus and impact strength of different weight percentage of fiber. It can be seen that flexural strength of different fiber weight showed a continuous increase with the increasing amount of fiber content in the composite. Ismail et al. [28] also found almost similar result where the addition of rice straw fiber increases the flexural and impact strength of rice straw/polyvinyl alcohol and rice straw/polystyrene. The author states that the increase is due to the mechanical interlocking between fibre and matrix. The fiber content of $10 \%$ fiber gives about $20.11 \%$ increase in flexural strength value compared to pure LDPE while $29.18 \%$ and $34.19 \%$ for $20 \%$ and $30 \%$ of fiber content respectively. The flexural modulus was also increased with the increasing of fiber weight percentage from $10 \%$ to $30 \%$. It was proved by the increase of flexural modulus of pure LDPE with the addition of fiber content. Atuanya et al. [23] observed the same pattern for flexural modulus of RLDPE/bean pod ash where the modulus increased with fibre content. The author identifies that this increase is due to the the increase in fibre to matrix interactions, increasing the dispersion of stress. For $10 \%$ fiber content, the increase of flexural modulus reported was $13.06 \%$. The increase in percentage of flexural modulus for $20 \%$ of fiber content was $39.64 \%$ and $48.02 \%$ for $30 \%$ fiber content. Although the flexural strength and flexural modulus was increasing with the increasing of fiber loading, the impact strength shows different result where impact strength was decreased with the increasing of fiber loading. The decrease in percentage of impact strength from $10 \%$ weight fiber to $20 \%$ weight fiber was $31.98 \%$ while the decrease from $20 \%$ to $30 \%$ weight fiber was $48.45 \%$.

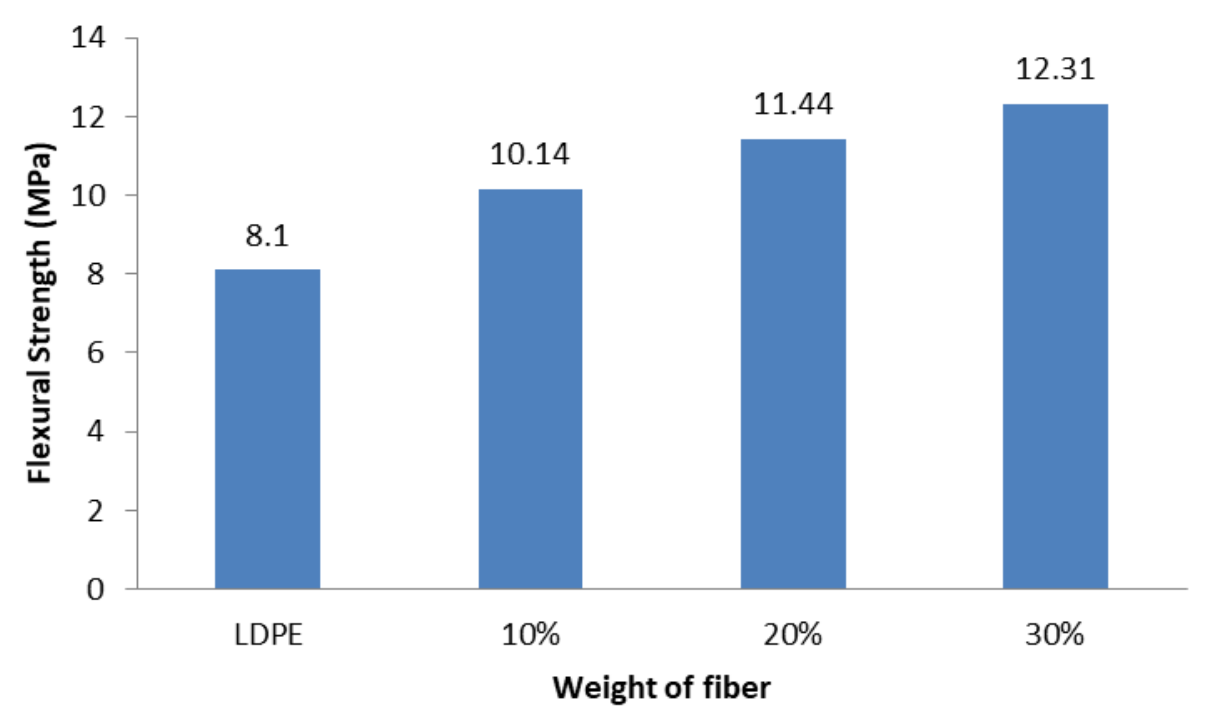

Figure 3. Flexural strength of composite with different fiber loading. 


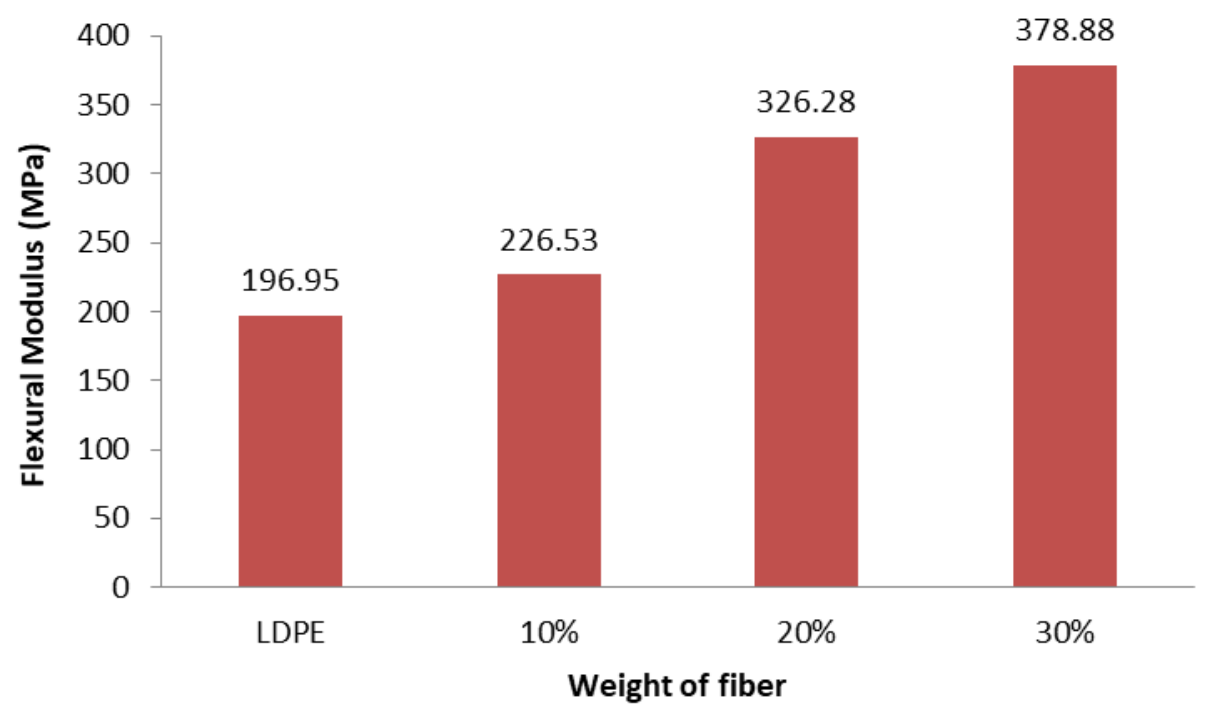

Figure 4. Flexural modulus of composite with different fiber loading.

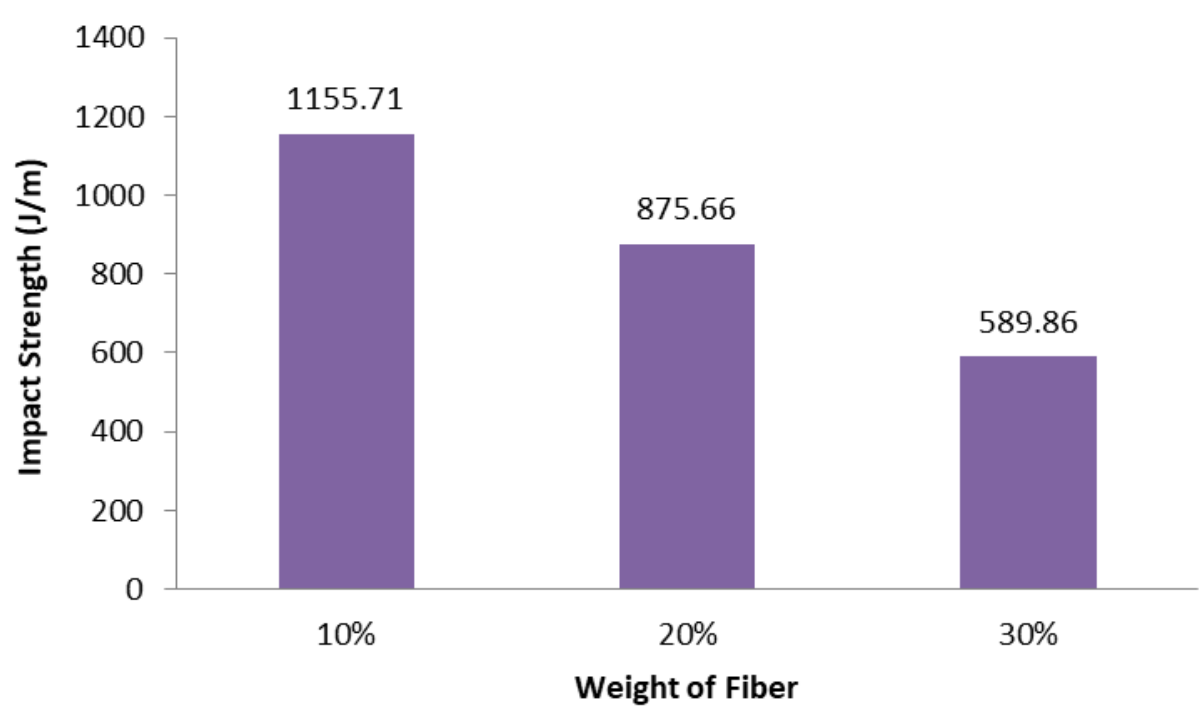

Figure 5. Impact strength of composite with different fiber loading.

The high particle orientation that hinders the chain movement during deformation was due to the fair distribution of fiber in the polyethylene matrix has led to the increasing of the stiffness and the modulus of the composite [27]. Moreover, the increase in the strength and modulus of the MLF composites indicates the increasing in the rigidity of polyethylene due to the mobility limitation in polyethylene matrix that contains MLF [27]. When the modulus was increased with the increase of fiber loading of MLF, the stress transfer across the polymer particles interface prevented the movement around each particle led to overall increase in modulus and strength [23]. The higher filler amount in the polyethylene and MLF composites resulted in stiffening and hardening of the composite thus reduced its resilience and toughness and possess low impact energy [23]. The other hypothesize was that the decrease in impact strength when increasing the filler content was due to the interfacial interaction between the matrix and filler was weak. Shih et al. [29] records that the impact strength of the composite reduces as the 
fibre content increases. The author argues that the addition of fibre improved the rigidness of the composite but changed the characteristic to be more brittle.

\section{Effect of different fiber length of MLF-LDPE composites}

Figure 6 to Figure 8 shows the flexural strength, flexural modulus, and impact strength for different fiber length. The fiber length used were $<0.5 \mathrm{~mm}, 0.5-1 \mathrm{~mm}$, and 1-2 $\mathrm{mm}$. From the Figure, it can be seen that the flexural strength was increased with the increase of fiber length Amuthakkannan et al [30] confirmed that the increase in length increases the capability to withstand higher bending load, thus increasing the flexural strength of the composite. The percentage of increase for the fibre length of $<0.5 \mathrm{~mm}, 0.5-1 \mathrm{~mm}$, and 1-2 mm compared to the pure LDPE was $20.11 \%, 36.51 \%$, and $37.02 \%$ respectively. The flexural modulus shows increasing trend with the increase of fiber length. Sumaila et al. [31] agreed that the increase in fiber length increases the flexural strength and the flexural modulus of the composite due to the increase of fiber to fiber contact. The value of flexural modulus increased with the increase of fiber length of MLF. For the length of $<0.5 \mathrm{~mm}$, it shows $13.06 \%$ of increase in flexural modulus while for the length of $0.5-1 \mathrm{~mm}$, the percentage of increase in flexural modulus was $21.80 \%$ and for $1-2 \mathrm{~mm}$ length shows $26.45 \%$ of increase.

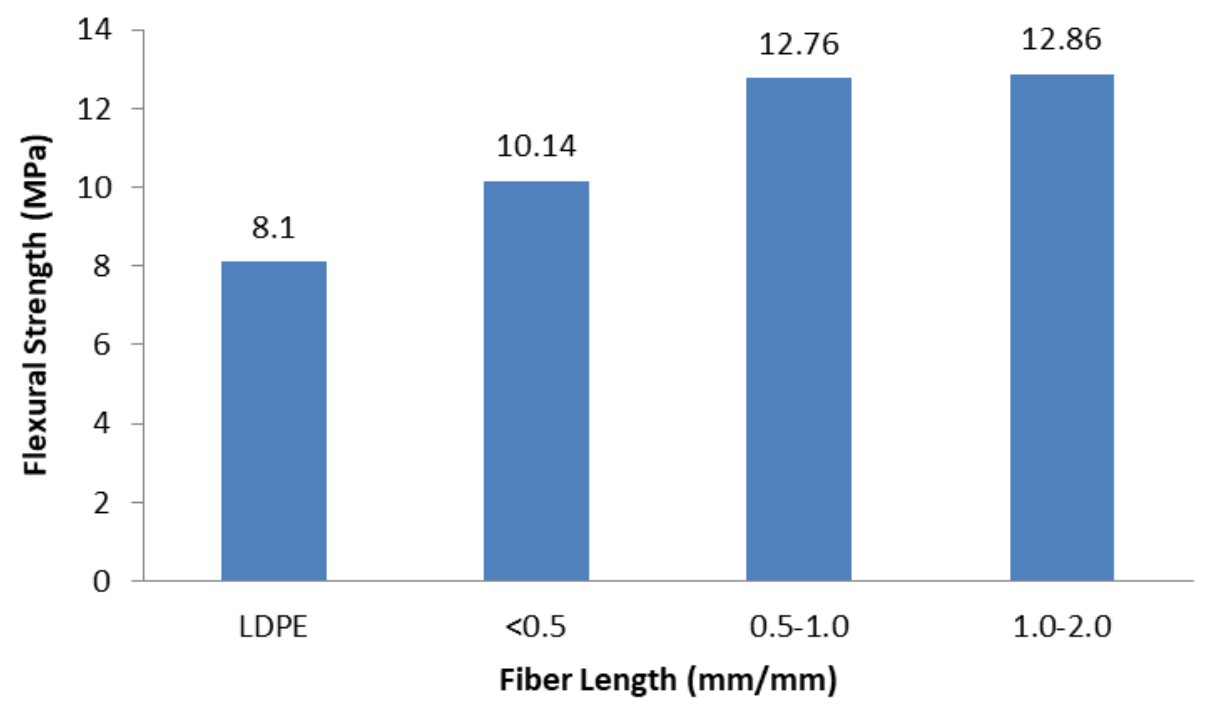

Figure 6. Flexural strength of composite with different fiber length. 


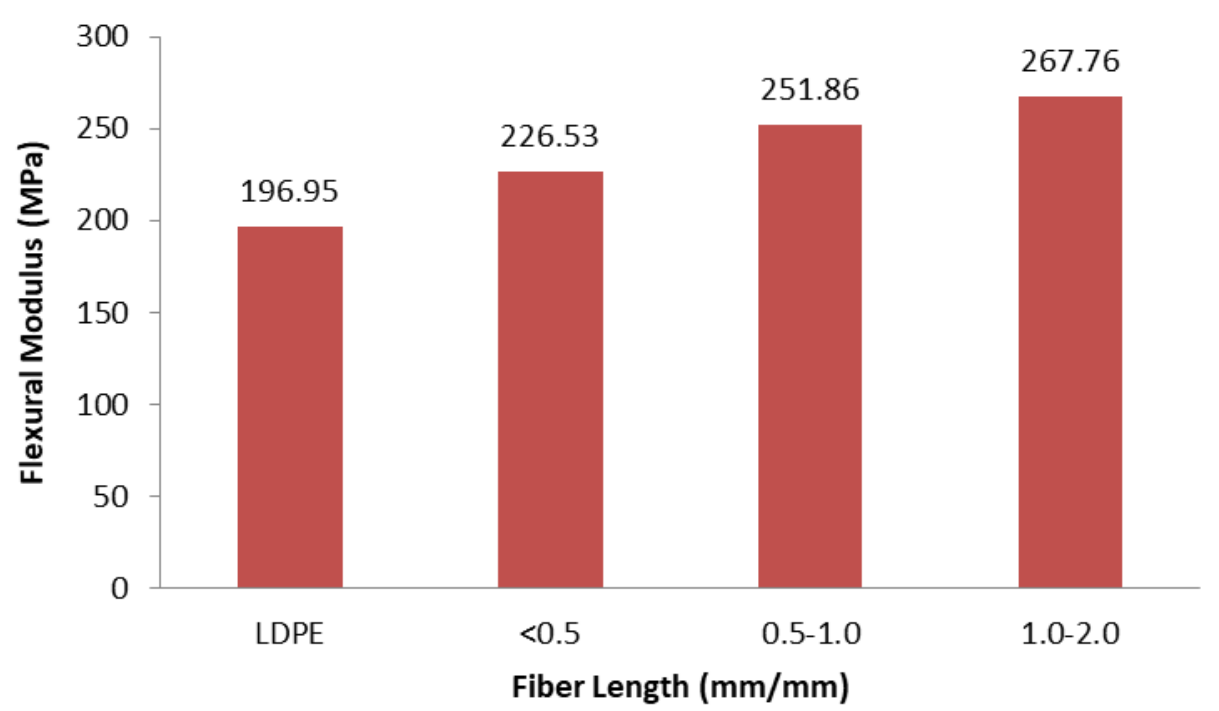

Figure 7. Flexural modulus of composite with different fiber length.

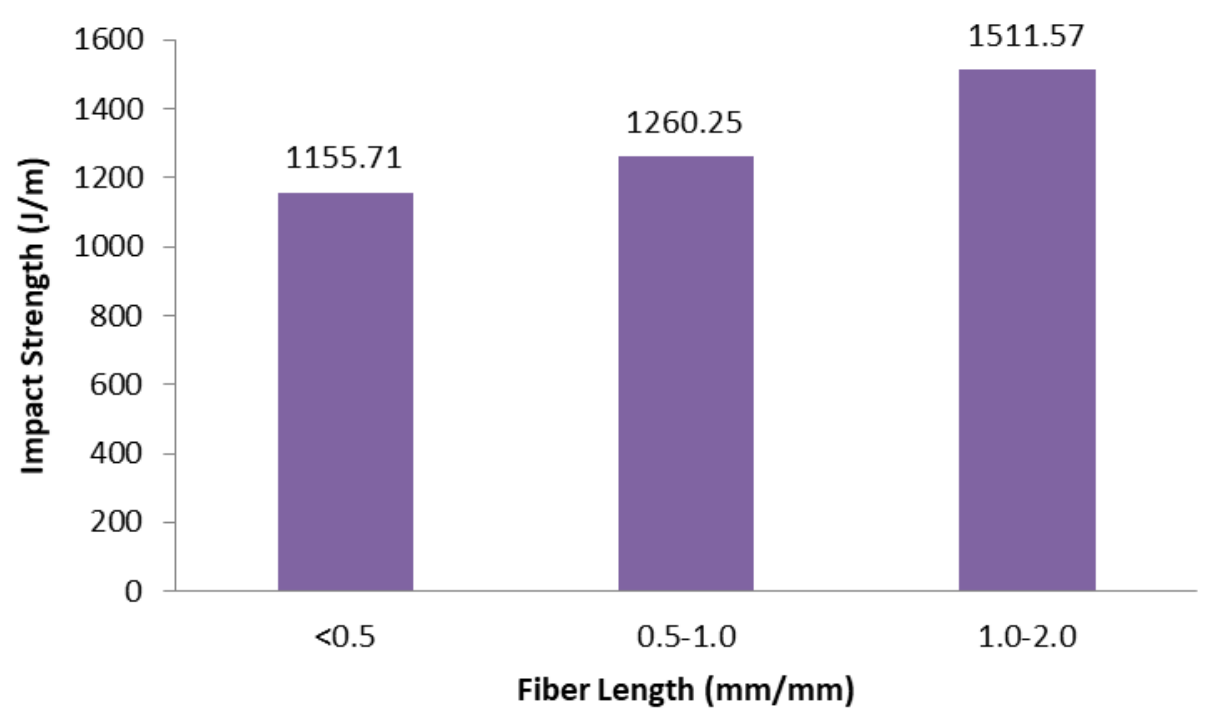

Figure 8. Impact strength of composite with different fiber length.

The impact strength for the MLF-LDPE composite was also increased with the increase of the fiber length. Pickering et al. [32] stated that the increase in fibre length offers better stress transfer and load bearing efficiency. The percentage of increment of impact strength of $<0.5 \mathrm{~mm}$ to $0.5-1 \mathrm{~mm}$ length fiber was $8.29 \%$ while for the length of $0.5-1$ $\mathrm{mm}$ to $1-2 \mathrm{~mm}$ fiber length, the percentage of increment was $16.63 \%$.

In term of the fiber strength, the longer fiber acts as the barrier to the crack propagation and withstands higher loads compared to shorter ones. It was obvious that the required energy to pull the shot fiber from the matrix was less that led to dissipation of energy [31] and advancing the crack propagation of the sample thus making the materials to be brittle [27]. Fiber length also affected the properties of MLF reinforced polyethylene where MLF with longer length could withstand a high load and tolerate more stress than shorter ones led to high flexural strength and modulus [33]. Biswas et al. [34] reported that the impact strength and flexural strength of coir fiber reinforced epoxy composites 
increases as the fiber length increases. It was hypnotized that the fibers plays an important role in term of fracture energy where the long fiber can hold greater strength in applied loading condition compared to shorter fiber in the polyethylene matrix before break. High in flexural strength can be achieved when there are strong interface between the fiber and matrix [30]. Long fiber also gives better resistance in crack propagation compared to shorter ones. It was reported in the research of mechanical and thermal properties of short carbon fiber that flexural strength, flexural modulus, and impact strength was increase with the increasing of fiber length [33].

\section{CONCLUSIONS}

From the result and discussion presented, it can be concluded that the work shows the addition of MLF in LDPE composites increased the flexural modulus, flexural strength, for different fiber content and different fiber length and the $30 \%$ fiber by weight is the best composition with the flexural strength and modulus of $12.31 \mathrm{MPa}$ and $378.88 \mathrm{MPa}$ for the composite whereby $1.0-2.0 \mathrm{~mm}$ is the best fiber length for the MLF-LDPE composites with the impact strength of $1511.57 \mathrm{~J} / \mathrm{m}$ and flexural strength of $12.86 \mathrm{MPa}$. This suggests that for applications where the flexural rigidity is required, composite fabricated from longer fibre length is desirable. It is also can agreed that the fabrication of MLF-LDPE composites by compounding and compression moulding process was successfully done. In future studies fibres should undergo surface modification to increase the available surface area for reaction to increase the strength of the composite by better mechanical interlocking.

\section{ACKNOWLEDGEMENTS}

The authors would like to thank to Universiti Malaysia Pahang for providing laboratory facilities and financial assistance under project no. RDU140307.

\section{REFERENCES}

[1] Yang Y, Ota T, Morii T, Hamada H. Mechanical property and hydrothermal aging of injection molded jute/polypropylene composites. Journal of Materials Science. 2010;46;8:2678-2684.

[2] Fuqua MA, Huo S, Ulven CA. Natural fiber reinforced composites. Polymer Reviews. 2012;52;3:259-320.

[3] Al-Oqla FM, Sapuan S.M. Natural fiber reinforced polymer composites in industrial applications: feasibility of date palm fibers for sustainable automotive industry. Journal of Cleaner Production. 2014;66:347-354.

[4] Saba N, Paridah, MT, Jawaid M. Mechanical properties of kenaf fibre reinforced polymer composite: A review. Construction and Building Materials. 2015;76:8796.

[5] Faruk O, Bledzki, AK, Fink, HP, Sain, M. Biocomposites reinforced with natural fibers: 2000-2010. Progress in Polymer Science. 2012;37:1552-1596. 
[6] $\mathrm{Ku} \mathrm{H}$, Wang $\mathrm{H}$, Pattarachaiyakoop $\mathrm{M}$, Trada $\mathrm{M}$. A review on the tensile properties of natural fiber reinforced polymer composites. Composites Part B: Engineering. 2011;42;4:856-873.

[7] Kengkhetkit N, Amornsakchai T. A new approach to "Greening" plastic composites using pineapple leaf waste for performance and cost effectiveness. Materials \& Design. 2014;55:292-299.

[8] Leao, AL, Fouza SF, Cherian BM, Frollini E, Thomas S, Pothan LA, Kottaisamy M. Agro-based biocomposites for industrial applications. Molecular Crystals and Liquid Crystals. 2010;522;1:318-327].

[9] Uma Devi L, Joseph K, Munikandan Nair KC, Thomas S. Ageing studies of pineapple leaf fiber-reinforced polyester composites. Journal of applied polymer science. 2004;94;2:503-510.

[10] Mngomezulu ME, John MJ, Jacobs V, Luyt AS. Review on flammability of biofibres and biocomposites. Carbohydrate Polymer. 2014;111p. 149-82.

[11] Arrakhiz F.Z, El Achaby M, Malha M, Besalah MO, Fassi-Fehri O, Bouhfid R, Benmoussa K, Qaiss A. Mechanical and thermal properties of natural fibers reinforced polymer composites: Doum/low density polyethylene. Materials \& Design. 2013;43:200-205.

[12] Mirmehdi SM, Zeinaly F, Dabbagh F. Date palm wood flour as filler of linear low-density polyethylene. Composites Part B: Engineering. 2014;56:137-141.

[13] Alam AKMM, Mina MF, Beg MDH, Mamun AA, Bledzki AK, Shubra QTH. Thermo-mechanical and morphological properties of short natural fiber reinforced poly (lactic acid) biocomposite: Effect of fiber treatment. Fibers and Polymers. 2014;15;6:1303-1309.

[14] Tezara C, Siregar JP, Lim HY, Fauzi FA, Yazdi MH, Moey LK, Lim JW. Factors that affect the mechanical properties of kenaf fiber reinforced polymer: A review. Journal of Mechanical Engineering and Sciences, 2016;10;2:21592175.

[15] Mohammed AA, BAchtiar D, Siregar JP, Rejab MRM. Effect of sodium hydroxide on the tensile properties of sugar palm fibre reinforced thermoplastic polyurethane composites. Journal of Mechanical Engineering and Sciences. 2016;.10;1:1765-1777.

[16] Lee CH, Sapuan SM, Lee JH, Hassan MR. Mechanical properties of kenaf fibre reinforced floreon biocomposites with magnesium hydroxide filler. Journal of Mechanical Engineering and Sciences. 2016;10;3;2234-2248.

[17] Azwa ZN, Yousif, BF, Manalo AC, Karunasena W. A review on the degradability of polymeric composites based on natural fibres. Materials \& Design. 2013;47:424-442.

[18] Marrot, L., et al., Multi-scale study of the adhesion between flax fibers and biobased thermoset matrices. Materials \& Design. 2014;62:47-56.

[19] Guo L, Chen F, Zhou Y, Liu X, Xu W. The influence of interface and thermal conductivity of filler on the nonisothermal crystallization kinetics of polypropylene/natural protein fiber composites. Composites Part B: Engineering. 2015;68:300-309.

[20] Jahan A, Rahman M, Kabir H, Kabir MA, Ahmed F, Hossain MA, Gafur MA. Comparative study of physical and elastic properties of jute and glass fiber reinforced LDPE composites. International Journal of Scientific and Technology Research. 2012;1;10:68-72. 
[21] Kuan HTN, Lee M.C. Tensile properties of pandanus atrocarpus based composites. Journal of Applied Science \& Process Engineering. 2014:1:1.

[22] Sunilkumar M, Francis T, Thachil ET, Sujith A. Low density polyethylenechitosan composites: A study based on biodegradation. Chemical Engineering Journal. 2012;204-206:114-124.

[23] Atuanya CU, Edokpia RO, Aigbodion V.S. The physio-mechanical properties of recycled low density polyethylene (RLDPE)/bean pod ash particulate composites. Results in Physics. 2014;4:88-95.

[24] Ho MP, Wang H, Lee JH, Ho CK, Lau KT, Leng J, Hui D. Critical factors on manufacturing processes of natural fibre composites. Composites Part B: Engineering. 2012;43;8:3549-3562.

[25] Quental AC, Felisberti MI. Phase behavior of blends of linear low density polyethylene and poly(ethene-propene-1-butene). European Polymer, Journal of International Economics. 2005;41:894-902.

[26] George J, Bhagawan SS, Prabhakaran N, Thomas S. Short pineapple-leaf-fiber-reinforced low-density polyethylene composites. Journal of Applied Polymer Science. 1995;57;7:843-854.

[27] Rosa SML, Santos EF, Ferreira CA, Nachtigall SMB. Studies on the properties of rice-husk-filled-PP composites: effect of maleated PP. Materials Research. 2009;12;3:333-338.

[28] Ismail MR, Yassen AAM, Afify MS. Mechanical properties of rice straw fiberreinforced polymer composites. Fibers and Polymers. 2011;12;5:648-656.

[29] Shih YF, Huang CC. Polylactic acid (PLA)/banana fiber (BF) biodegradable green composites. Journal of Polymer Research. 2011;18;6:2335-2340.

[30] Amuthakkannan P, Manikandan V, Winowlin Jappes JT, Uthayakumar M. Effect of fibre length and fibre content on mechanical properties of short baslat fibre reinforced polymer matrix composites. Materials Physics and Mechanics. 2013;16:107-117.

[31] Sumaila M, Amber I, Bawa M. Effect of fiber length on the physical and mechanical properties of ramdom oriented, nonwoven short banana (musa balbisiana) fibre/epoxy composite. Cellulose. 2013;62:64.

[32] Pickering KL, Efendy MA, Le TM. A review of recent developments in natural fibre composites and their mechanical performance. Composites Part A: Applied Science and Manufacturing. 2016;83:98-112.

[33] Rezaei F, Yunus R, Ibrahim NA, Mahdi ES. Effect of fiber loading and fiber length on mechanical and thermal properties of short carbon fiber reinforced polypropylene composites. The Malaysian Journal of Analytical Sciences. 2007;11;181-188.

[34] Biswas S, Kindo S, Patnaik A. Effect of fiber length on mechanical behavior of coir fiber reinforced epoxy composites. Fibers and Polymers. 2011;12;1:73-78. 